ACTA MYCOLOGICA

Vol. 45 (2): 157-162

2010
Dedicated to Professor Barbara Gumińska on the occasion of her eighty-fifth birthday

\title{
Entoloma jahnii, a rare species in Europe
}

\author{
JOANNA NITA and MATEUSZ STEFANIAK \\ Department of Plant Ecology and Environmental Protection, Adam Mickiewicz University \\ Umultowska 89, PL-61-614 Poznań, malav@wp.pl, afanit@op.pl
}

Nita J., Stefaniak M.: Entoloma jahnii, a rare species in Europe. Acta Mycol. 45 (2): 157-162, 2010.

The authors describe two localities of Entoloma jahnii Wölfel \& Winterh., which were found during the mycocoenological research in Pomerania and Wielkopolska Regions in the phytocoenoses of Carici elongatae-Alnetum and Galio sylvatici-Carpinetum associations. The article consists of a description of gathered specimens and some remarks concerning ecology of this rare species.

Key words: mycocoenology, Pomerania region, Wielkopolska region, Carici elongataeAlnetum, Galio sylvatici-Carpinetum

\section{INTRODUCTION}

Entoloma jahnii is one of three members of section Claudopus in Poland (Wojewoda 2003), which are characterized by pleurotoid or omphalinoid basidiocarps and excentric or absent stipe.

It was described for the first time from Germany by Wölfel and Winterhoff (1993). Since then it was rarely found in several other European countries. In Poland this species was found in two localities: Lipka Forest Inspectorate (Pomerania Region) and Krajkowo nature reserve (Wielkopolska Region). The aim of this paper it to contribute to the present knowledge on distribution and ecology of this species. 


\section{MATERIALS AND METHODS}

The study was based on materials gathered by the authors in 2003-2006 and 2009 during the mycocoenological research in the western Poland.

The first locality refers to Lipka Forest Inspectorate (Fig.1) (Nita, Bujakiewicz 2007, 2009), where the specieswas collected in the phytocoenosis of the Caricielongatae-Alnetum association in Potulice forestry (plot size $400 \mathrm{~m}^{2}$ ). The alder forest is characterized by a very well developed mosaic structure of the herbal layer, with high hummocks built by Alnus glutinosa with an admixture of Picea abies in various ages. The hummocks are covered by thick carpets of mosses (mainly Mnium hornum, Amblystegium varium and Amblystegium riparium). On clusters, among mosses, occur various ferns, among others Dryopteris dilatata, Thelypteris palustris and Athyrium filix-femina. On the organic soil of the boggy hollows grow Hottonia palustris, Oeananthe aquatica, Solanum dulcamara, Urtica dioica, Carex acutiformis and Carex elongata. The hollows remain flooded for most of the year (at least 7 months). Logs and boughs of alder, spruce and birch in various stages of decomposition cover the bottom of the forest.

The second locality refers to Krajkowo nature reserve (Konstantynowo Forest Inspectorate) (Fig.1). The reserve is situated in the river Warta valley, about $35 \mathrm{~km}$ south of Poznan. This species was found in the permanent observation plot located in the Galio sylvatici-Carpinetum phytocenosis. This phytocenosis is part of the larger complex with spatial contact with Querco-Ulmetum minoris association. The plot $\left(400 \mathrm{~m}^{2}\right)$ in Krajkowo reserve is characterized by extremely different ecological conditions than the one in Lipka Forest Inspectorate. The phytocenosis in which the species was found is mesophilous and is never flooded. It offers different substrates (the tree layer consists of Quercus robur, Pinus sylvestris, Carpinus betulus, Ulmus leavis) for the wood-rotting fungi and different moisture conditions.

The specimens gathered were identified on the base of the description of Entoloma jahnii Wölfel \& Winterhoff 1993 in Noordeloos (2004). The observations of microscopic characters were made on fresh material in $\mathrm{H}_{2} \mathrm{O}$ and in $25 \% \mathrm{NH}_{4} \mathrm{OH}$ solution. Measurements and drawings were made under $400 \mathrm{x}$ with Carl Zeiss Jenaval microscope. Spore dimensions are based on 20 observations of spores from both collections.

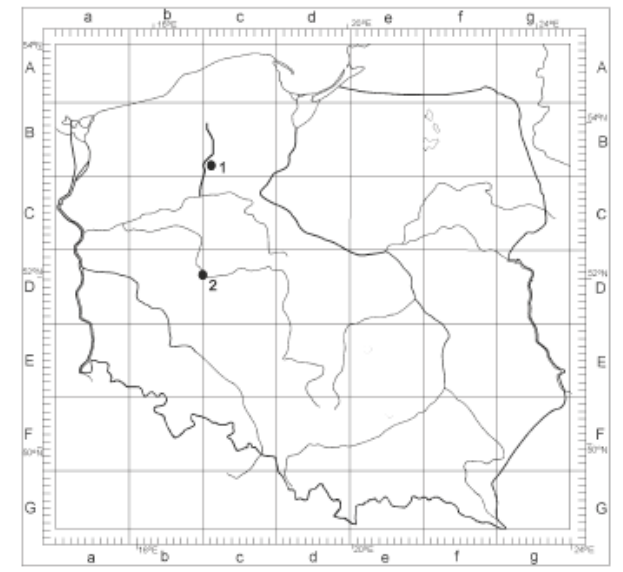

Fig. 1. Localities of E. jahnii in Poland: 1 - Lipka Forest Inspectorate, 2 - Krajkowo nature reserve. 


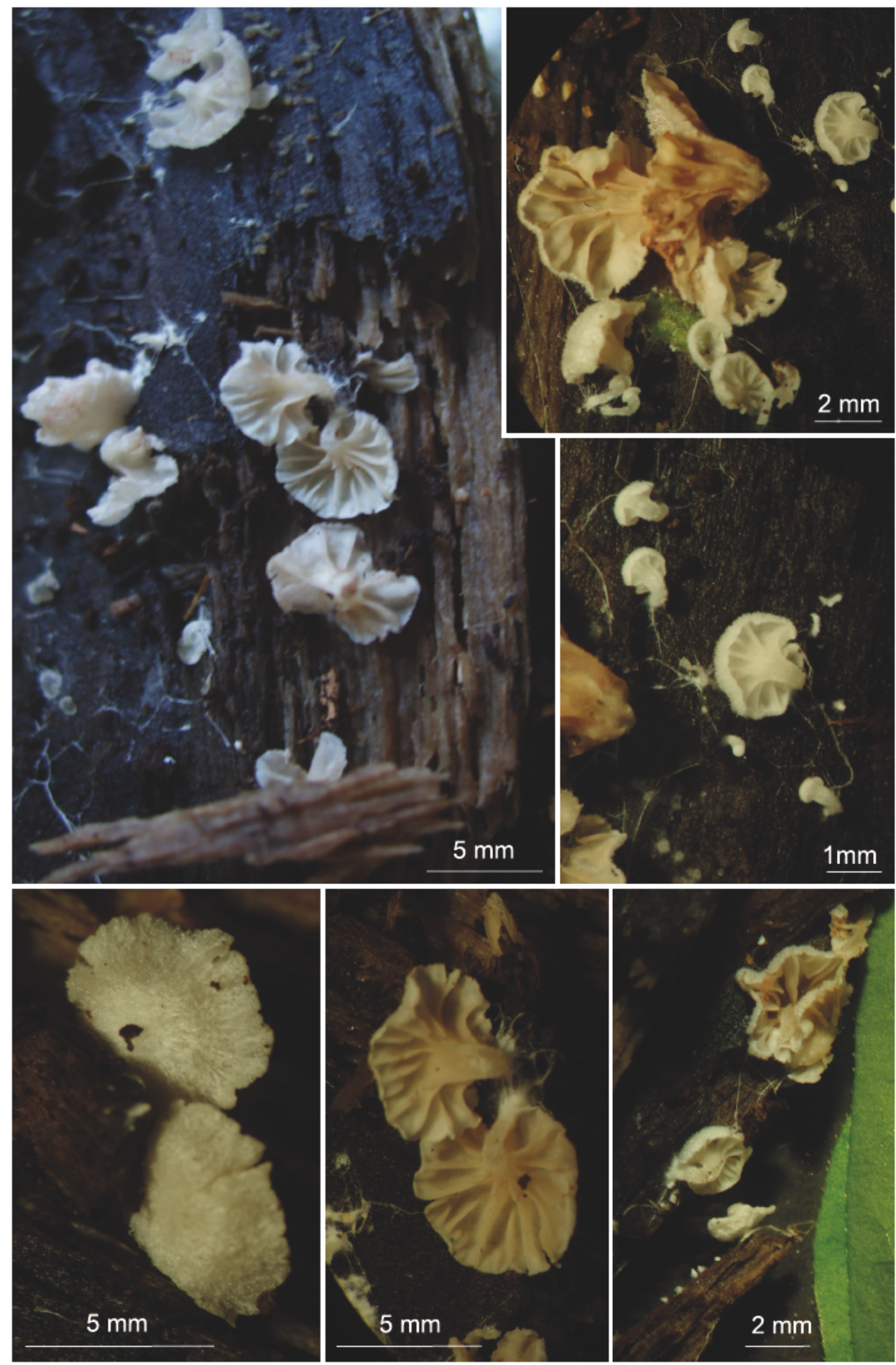

Fig. 2. Fresh carpophores of E. jahnii (phot. M.Nita). 
The collections were deposited at the Herbarium of the Department of Plant Ecology and Environmental Protection (POZM), the Adam Mickiewicz University, Poznań.

\section{RESULTS}

The description refers to specimens from the first locality. Characteristic features of the collected carpophores agree essentially with diagnoses given by Noordeloos (2004).

Pileus pleurotoid (Fig. 2), 1-8 mm wide, white, very thin (translucent), strongly pubescent, especially in the center, at the margin translucently striate and crenulated.

Stipe 1-3 mm long, 0.5-1 mm wide, excentric, sometimes rudimentary, bent, white and hairy. In the upper part slightly widened, at the base with long mycelium, which covers the substrate radially from the point of attachment.

Lamellae slightly or strongly decurrent, first white, then with pink tint, at maturity salmon pink, mixed, quite wide and thick.

A

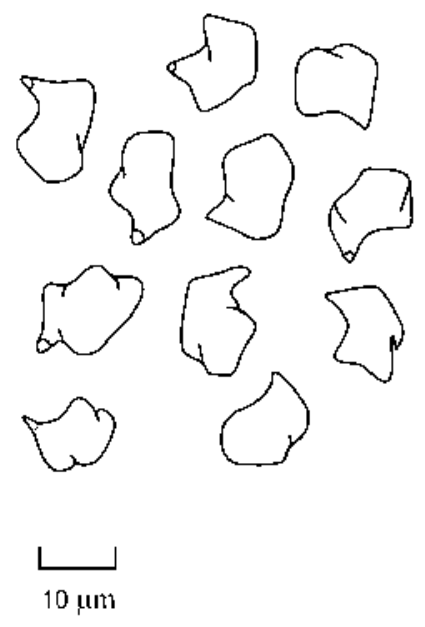

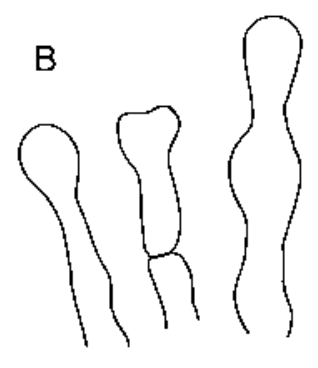
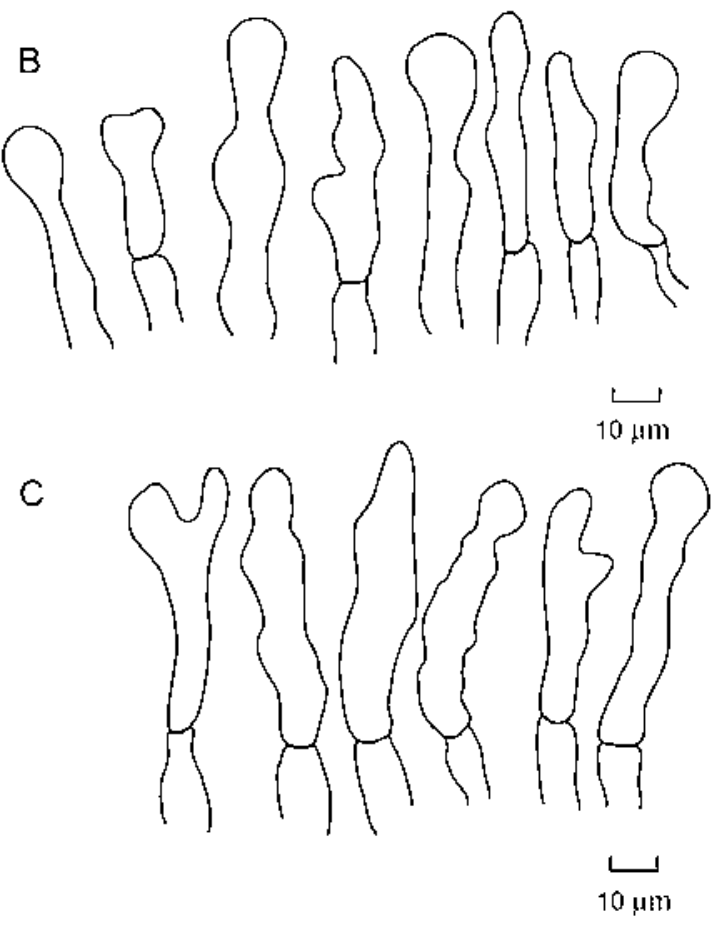

Fig. 3. Microscopic elements of E. jahnii: spores (A), capitate and cylindrical hyphae on the stipe (B) and the cap (C) surface. 
Basidia mostly 4-spored, rarely 2-spored, with clamps. Cheilo- and pleurocystidia absent. Sporae 9.4-12.5 (15) (refers to the second locality) x 6.9-10 $\mu \mathrm{m}$, variable in shape (Fig. 3 A), iso- and heterodiametric, 5 to 6 angled. The surface of stipe and cap with protruding capitate and cylindrical hyphae (Fig. $3 \mathrm{~B}, \mathrm{C}$ ). Clamp connections present.

In Lipka Forest Inspectorate during summer and autumn visits carpophores of Entoloma jahnii were observed on a rotten log of Betula (leg. J. Nita). They were growing on the underside of the log, which was soaked in the boggy bottom, just after a periodical flood. The number of carpophores varied during the observation period of 3 years (8 visits) from 1 to over 100. During two observations carpophores of Entoloma jahnii were accompanied by Pluteus podospileus.

In Krajkowo reserve ten carpophores of this species were found on the small piece of wood which was part of an old and well decayed log of probably Quercus robur or Carpinus betulus lying on the ground among the Dryopteris filix-mas and other plants. This was the moistest part of the plot. No other species of fungi were found on this piece of wood. The species was found only once, on July 29th 2009 (leg. M. Stefaniak).

\section{DISCUSSION}

Until recently, Entoloma jahnii has been reported from Poland only from the locality in Lipka Inspectorate Forest. Krajkowo nature reserve is the second locality of this species.

This saprotrophic species has been noted in Germany (Krieglsteiner 2003), Belgium (Noordeloos 2004), Denmark (Læssøe 2008), Finland (Noordeloos 2008), Sweden (Ludwig 2007) and in the British Isles (Schafer 2008), where it was found on barked, rotten wood of frondose tree species: Alnus, Betula, Populus, Fraxinus and Quercus. The species is regarded to be confined to moist and dry deciduous forests and copses (Noordeloos 2004). It also shows the association with frondose tree species. This species was found by the authors in two forest associations which offer different ecological conditions, the main differences are moisture conditions and availability of wood of different tree species. The locality in Lipka Forest Inspectorate was temporarily flooded, whereas Krajkowo nature reserve is rather dry and never flooded. The first locality offered also different substrates (Alnus glutinosa, Betula sp.) compared to Krajkowo nature reserve (Quercus robur, Carpinus betulus, Ulmus leavis).

The localities show full scale of substrates and ecological conditions in which this species can occur - from moist to mesophilous forest associations. Entoloma jahnii is red-listed in the Mecklenburg-Vorpomernn region (Schwik et al. 1999), and in Denmark (The Danish Red Data Book 2010). Fruitbodies of this species are frequently found in hidden places, such as the underside of logs, branches, or pieces of wood (Noordeloos 2004), and can be easily overlooked. This feature seems to be one of the reasons of its rarity, nevertheless in our opinion this species is really rare in Poland. In recent years many studies on macrofungi were conducted in broadleaved forests and copses (e.g., Bujakiewicz 1989; Bujakiewicz et al. 2005; Bujakiewicz, Stefaniak 2009; Friedrich 1994; Kujawa 2009; Lisiewska, Malinger 2001; Ławrynowicz 
et al. 2002; Nita, Bujakiewicz 2005) in which, according to literature and the author's own observations suitable ecological conditions occur; still the species is known only from two localities. In our opinion it would be appropriate to include this species on the Polish Red List (Wojewoda, Ławrynowicz 2006) with the category E.

Acknowledgements. Authors would like to thank Prof. Anna Bujakiewicz for her valuable comments and discussion on our manuscript. We are grateful Mr. Mieczysław Nita for his kind permission to use his photographs and Miss Magdalena Stefaniak for improving the language. We are also indebted to the anonymous reviewer for useful suggestions that helped to improve our work. The study was supported by Ministry of Science and Higher Education, grants nos. N304 06031 and N304 043639.

\section{REFERENCES}

Bujakiewicz A. 1989. Macrofungi in the alder and alluvial forests in various parts of Europe and North America. Opera Bot. 100: 29-41.

Bujakiewicz A., Nita J., Bałazy S. 2005. First localities of the recently described fungus - Cordyceps bifusispora O. E. Ericksson. Acta Mycol. 40 (2): 251-258.

Bujakiewicz A., Stefaniak M. 2009. Udział macromycetes w fitocenozach leśnych rezerwatu „Las Liściasty w Promnie" (nadleśnictwo Czerniejewo). Bad. Fizjogr. Pol. Zach., B, 58: 137-170.

Friedrich S. 1994. Charakterystyka socjologiczno-ekologiczna mikoflory zbiorowisk roślinnych Cedyńskiego Parku Krajobrazowego. Akademia Rolnicza w Szczecinie, Rozprawy 161: 1-100.

Kujawa A. 2009. Macrofungi of wooded patches in the agricultural landscape. I. Species diversity. Acta Mycol. 44 (1): 49-75.

Krieglsteiner G. J. (ed.) 2003. Die Großpilze Baden-Württembergs. Band 4 Ständerpilze: Blätterpilze II. Verlag Eugen Ulmer, Stuttgart.

Ławrynowicz M., Dziedziński T., Szkodzik J. 2002. Macrofungi of Aceri-Tilietum and Tilio-Carpinetum in the „Dolina Rzeki Brdy“ nature reserve in the Bory Tucholskie (NW Poland). Acta Mycol. 37 (1/2): 63-76.

Lisiewska M., Malinger M. 2001. Macromycetes w różnych postaciach grądu środkowoeuropejskiego na terenie uroczyska Marcelin w Poznaniu. Bad. Fizjogr. Pol. Zach. B, 50: 7-40.

Ludwig E. 2007. Pilzkompendium. Band 2. Beschreibungen. Fungicon Verlag, Berlin.

Læssøe T. 2008. Muslinge-Rødblad (Entoloma jahnii) - nu også i Danmark Svampe 57: 34-35.

Nita J., Bujakiewicz A. 2005. Grzyby wielkoowocnikowe w fitocenozach łęgu wiązowego Querco-Ulmetum minoris i olsu Carici elongatae-Alnetum w Lesie Złotowskim (Pomorze Zachodnie). Bad. Fizjogr. Pol. Zach. Ser. B, 54: 7-33.

Nita J., Bujakiewicz A. 2007. Łęgi i olsy ostoją rzadkich i zagrożonych grzybów wielkoowocnikowych. Studia i Materiały Centrum Edukacji Przyrodniczo-Leśnej. Siedliska i gatunki wskaźnikowe w lasach. $9(2 / 3): 519-529$.

Nita J., Bujakiewicz A. 2009. Riparian and alder forests - shelters for rare and threatened macromycetes (In:) Z. Mirek, A. Nikel (eds). Rare, relict and endangered plant and Fungi in Poland. W. Szafer Institute of Botany, Polish Academy of Sciences, Kraków: 325-334.

Noordeloos M. E. 2004. Fungi Europaei 5a. Entoloma s.1. Supplemento. Edizioni Candusso. Italia.

Noordeloos, M. E. 2008. Entoloma (Fr.) P.Kumm. (In:) H. Knudsen, J. Vesterholt (eds). Funga Nordica. Agaricoid, boletoid and cyphelloid genera. Nordsvamp-Copenhagen.

Schwik J., Westphal B., Bütow R., Michael H., Richter K., Schurig B. 1999. Rote Liste der gefährdeten Großpilze Mecklenburg-Vorpommerns. 2. Fassung. Stand: November 1999. Umweltministerium des Landes Mecklenburg-Vorpommern, Schwerin.

Schafer D. 2008: Persistence pays off - Entoloma jahnii, a new British record. Field Mycology: 9 (2): 49-50.

The Danish Red Data Book. National Environmental Research Institute, http://www2.dmu.dk/

Wojewoda W. 2003. Checklist of Polish larger Basidiomycetes. (In:) Z. Mirek (ed.). Biodiversity of Poland 7: 1-812. W. Szafer Institute of Botany, Polish Academy of Sciences, Kraków.

Wojewoda W., Ławrynowicz M. 2006. Red list of the macrofungi in Poland. (In:) Z. Mirek, K. Zarzycki, W. Wojewoda, Z. Szeląg (eds). Red list of plants and fungi in Poland. 3. ed.: 53-70. W. Szafer Institute of Botany, Polish Academy of Sciences, Kraków.

Wölfel G., Winterhoff W. 1993. Entoloma jahnii, ein neuer Holzbewohner. Österr. Z. Pilzk. 2: 11-14. 
Entoloma jahnii, gatunek rzadki w Europie

\section{Streszczenie}

Artykuł zawiera informację na temat dwóch stanowisk Entoloma jahnii Wölfel \& Winterh. w Polsce. Gatunek ten notowano w Nadleśnictwie Lipka (Pojezierze Krajeńskie) oraz w rezerwacie przyrody „Krajkowo” (Wielkopolska), w fitocenozach Carici elongatae-Alnetum oraz Galio sylvatici-Carpinetum, podczas wieloletnich badań mikocenologicznych na stałych powierzchniach badawczych.

W pracy zawarto szczegółowy opis i ilustracje cech zebranych owocników tego gatunku, oraz uwagi dotyczące jego rozmieszczenia i ekologii. Autorzy podkreślają powiązanie E.jahnii z lasami i zaroślami liściastymi, oraz proponują ujęcie tego gatunku na czerwonej liście grzybów wielkoowocnikowych w Polsce. 